\title{
Determinants of Viability of Islamic Banking Products: A Case Study of Jaiz Bank Plc
}

\author{
Malanta S. Abdullahi, Adamu Kuku Usman and Nuraddeen M. Lawal \\ Economics Department, Yobe State University Damaturu, Nigeria
}

\begin{abstract}
This paper investigates the long-term prospects of Islamic banking products in Nigeria amidst the rising popularity/acceptability of non-interest banking, especially the Islamic banking system. The rationale is to examine how the products of Islamic Banks contribute to the banks' level of profitability and to also find out what factors affect the viability of Islamic banking products. Jaiz Bank Plc being the first official Islamic bank to be introduced into the Nigerian banking sphere is considered as a case study. The range of products/services offered by the bank are investigated in detail as well as their viability, keeping in mind the socio-economic and demographic factors prevailing in the environment. Data were sourced primarily with the help of a structured questionnaire. Discrete choice models were used as the econometrics tools of data analysis and the impact of seven variables was assessed on the viability of Islamic banking products. Also, Heteroskedasticity, Multicollinearity and F. tests were all conducted to ascertain the validity of the analysis. Six independent variables were found to be statistically significant at $1 \%$ levels and conform to a priori expectations. While the remaining variable even though it conformed to a priori expectations; was not found to be statistically significant. The research discovered that Islamic banking products are viable enough to add to the bottom line/profitability of Islamic financial institutions.
\end{abstract}

Keywords: Islamic Banking Products, Viability, Determinants, Jaiz Bank Plc

JEL Classification Numbers: E44, G10, G20

\section{INTRODUCTION}

I slamic banking is systematically growing in importance in some countries and in many others, too significant to be ignored. Since its emergence in its modern form in 1963, slightly less than a half-century, Islamic banking has become an indispensable part of the global financial system that is catering for not only the specific need of the Muslim community but also non-Muslims who want to pursue their economic activities without interest. Since the late 1990s, as a viable and competitive form of financial intermediary, Islamic banking has provided a wide range of financial products and services not only in Muslim countries but also in the secular world and has gained international recognition (Dogarawa, 2011).

Over the last decade, Islamic banking services have seen a sharp rise globally and have begun to provide a real and attractive alternative to the sort of financial services most people have become accustomed to. As of 2017, the total worth of the Islamic finance industry across its three main sectors (banking, capital markets, and TAKAFUL), was estimated to be USD 2.05 trillion - which represents $8.3 \%$ growth from the preceding two years. Islamic banking is the largest sector amongst the three, contributing $71 \%$ or USD 1.72 trillion. In the Middle East, Africa, and Asia, Islamic banking has become an important financial management tool, while it is also emerging in Western economies that were not normally associated with it in the past.

According to the Global Islamic Finance Market's report of 2019, there were 505 Islamic banks in 2017, and financial institutions spread in more than 75 countries and about 207 Islamic banking windows. Islamic banking, which is currently concentrated in the Middle East, North Africa, and South-East Asia, is gradually expanding its wings to sub-Saharan Africa, Central Asia, and Western Europe (Singh, 2013).

One of the most important goals of Islam is to achieve greater justice in human society. This is possible only if all human institutions, including the financial system, actively contribute towards this end. One of the needs for this is to align all aspects of human life: social, economic, political, and financial, to moral values. This will help curb the human greed and avarice that have made wealth maximization and want satisfaction as the highest measure of human achievement (Galbraith, 1972). Islamic banking products can suit everyone, regardless of religious beliefs; but especially for Muslims, interest is strictly forbidden and that is why Islam has its economic system which is based on social justice and promotion of social welfare of humanity (Oyeniran, 2012).

At the heart of the Islamic banking debate, is the questionability of the viability of its products by many critics. The importance of product/service's viability in any business can never be downplayed, as it is one of the key determinants of its success and also boost investors' confidence in that business venture. Business viability can be measured by its long-term survival, and its ability to have sustainable returns over time, sufficient enough to meet its financial obligations and provides a reasonable return to the investors. Profit forms the centre-stage of the economic viability of any business as its ability to survive depends on how it continues to make a profit year in year out. Business viability covers a broad area ranging from financial, management, market, to product viability. The number of viable products an organization has today determines its strength tomorrow.

Determining the viability of Islamic banking products is a major challenge presently facing the Islamic banking industry. In practice, many of the products of Islamic banks like 
Murabaha (cost plus) contracts cannot be discounted, highly rated liquid short-term assets are scarce in supply, and often there may be no lender of last resort to Islamic banks (Amin $e t$ $a l$, 2011). Islamic banks are almost $50 \%$ more liquid than their conventional counterparts. Islamic banks are expected to manage their excess liquidity according to Shariah legal provisions. Therefore, Islamic banks are limited in their ability to manage liquidity, especially in the short and medium terms, to earn returns and satisfy the demand of their depositors. With excess liquidity, the liquid assets are either generating no return, or where a return is generated it is at a very low level. This poses a serious business risk by affecting the competitiveness of the Islamic financial institutions negatively (Abdul-Majid, 2003). The causes of liquidity problems surrounding Islamic banks and financial institutions according to Abdul-Majid (2003) includes a small number of participants both customers and investors, the slow development of Islamic financial instruments, lack of Islamically acceptable inter-bank market, the absence of a liquid Islamic secondary market, no lender of last resort facilities and different Shariah interpretations from scholars.

In addition, Islamic banks lack flexible Shariah-compliant liquidity management tools, which manifests in the form of very short-term deposit liabilities, long-term investments, investors holding "Sukuk" issuances to maturity, many Islamic banks placing their surplus funds with conventional banks, the small size of the Islamic financial institutions and low level of cooperation among Islamic banks (Ibrahim et al, 1998).

This study examined the factors that determine the viability of JAIZ bank products as no previous study has investigated the variables that determine the viability of these products. This is because the concept of non-interest banking is new to Nigeria and JAIZ bank is the first-ever full-fledged Islamic bank in the country, as such only a handful of research has been done in that direction.

This research is of paramount importance to the financial sector regulators, particularly, the Central Bank of Nigeria (CBN), Nigeria Deposit Insurance Corporation (NDIC), Securities and Exchange Commission (SEC), and Nigerian Stock Exchange (NSE). It provides significant information that will enable the regulatory agencies to formulate sound financial policies that are peculiar to Islamic Banks. This will also contribute to proper monitoring and evaluation of Islamic Banks' accounts, especially with regards to their growth, survival, and competitiveness.

Since one of the objectives of banks is to manage liquidity, this study will influence the direction and management of liquidity not only in JAIZ Bank but also in non-interest banking systems. Thus, it will create and contribute to the existing literature in the areas of liquidity management and profitability in the Islamic banking system. Furthermore, financial analysts will find the research useful in the course of their economic and financial analysis, especially in terms of the specific needs of Islamic Banks. In addition, investors, customers, and other participants will be able to make a firm decision in the light of the research regarding their transactions and business dealings with Islamic Banks.

The first part of this study critically reviewed, in brief, the debate surrounding the viability of Islamic banking products. The second section identifies the conceptual, theoretical, and empirical literature. The third section discusses the research methodology, study area, sampling techniques, mode of data collection, model specification, and econometric tool for analysis. The other two sections deal with result analysis and discussions, conclusion, and policy recommendations, respectively.

\subsection{Background to the Study}

JAIZ Bank Plc was created out of the ashes of the former JAIZ International Plc which was set up in 2003/2004 as a special purpose vehicle (SPV) to establish Nigeria's first fullfledged Non-Interest Bank. On the 11th of November 2011, the Bank obtained a Regional operating license from the Central Bank of Nigeria to operate as the first Non-Interest Bank in Nigeria and began full operations on the 6th of January, 2012 with 3 branches located in the Federal Capital Territory (FCT) Abuja, Kaduna, and Kano. The Regional license allows the Bank to operate geographically in one-third part of the country. Also, based on recommendations from Islamic Development Bank (IDB), JAIZ Bank Plc has partnered with Islamic Bank Bangladesh (IBBL) for Technical and Management Assistance.

JAIZ Bank Plc was upgraded to a National operating license by 2013. Consequently, it has increased its Share Capital Base from N6 billion (USD39 million) in 2012 to N29.46 billion (USD 70 million) in 2019. This upgrade enables the Bank to operate in all 36 states of the Federation including the Federal Capital Territory, thereby, positioning it to compete effectively in one of the most thriving sectors of the Nigerian economy.

However, as of today, JAIZ bank is operating with a National license and have a total number of twenty-seven branches spread across nine states (Kano, Kaduna, Borno, Katsina, Rivers, Lagos, Zamfara, Sokoto, Adamawa, Bauchi, Oyo, and Gombe) and the FCT with Kano alone having three branches and a cash center. JAIZ bank in Nigeria, like other Islamic banks, offers a range of products that can be categorized into four; exchange-based products, lease-based products, partnership-based products, Kafalah-based products.

The most recent significant development in the Nigerian banking industry sphere is the emergence of the interest-free banking model which led to the establishment of the Islamic banking system and the country's first-ever full-fledged Islamic bank - Jaiz Bank. Other Islamic banks that emerged after Jaiz Bank includes TAJ and Lotus Banks.

A business's viability is measured by its long-term survival, and its ability to make sustainable profits over a long period of 
time. If a business is viable, it can survive for many years because it remains profitable year after year. The longer the business remains profitable, the better its viability. The number of viable products a business venture has today determines its strength tomorrow. The purpose of this study is to examine the determinants of the viability of Islamic banking products using JAIZ Bank Nigeria Plc as a case study. Doing so will assist in identifying the variables that are responsible for determining the viability of the bank's array of products. It is important to examine the determinants of Islamic banking products' viability since the concept is relatively new to this country and in recognition of the expectation of the coming on board of many other Islamic banks in the Nigerian financial market.

\subsection{Objectives of the Study}

The study aims to assess the determinants of the viability of Islamic banking products offered to customers by JAIZ Bank Plc. However, the specific objectives of the research include the following: -

i. To identify the determinants of viability for JAIZ Bank products.

ii. To assess the extent of the contribution of liquidity management to the

profitability of the Bank.

iii. To examine the impact of customer satisfaction on products offered by JAIZ

Bank Plc.

\section{LITERATURE REVIEW}

\subsection{Concept of Islamic Banking and Finance}

Islamic bank is an innovation in the banking industry. Organization of Islamic Conference (OIC) defined an Islamic bank as "a financial institution whose statutes, rules and procedures expressly state its commitment to the principles of Islamic Shariah and the banning of the receipt and payment of interest on any of its operations". Similarly, according to Ahsan (1988) an Islamic bank is "a financial and social institution whose objectives and operations as well as principles and practices must conform to the principles of Shariah which avoid the use of interest in any of its operations. It stands for an alternative financial system based on Islamic ideals. It is not only a financier but also a partner in productive economic development".

By providing risk-sharing instruments whose payoffs fluctuate with economic output and do not structurally impair the economy in the manner of excessive fixed-interest debt as does in a poor economic environment such as a recession, Islamic banking aimed to promote inclusive economic growth and development (Asquith et al, 1994). Therefore, the Islamic banking system is different from the interest based-system where the risk is mainly borne by the entrepreneur regardless of whether the entrepreneur makes a profit or incurs a loss. In other words, we can refer to Islamic banks as participatory banking in which its depositors are regarded as customers with some ownership rights (Alam, 2003).

Islamic banks, therefore, like their conventional counterpart, act as an intermediary and trustee of other people's money with the possible difference that the payoff to all its depositors is a share in profit and loss in one form or the other. In practice, however, Islamic banks are almost the same as traditional banks in terms of organizational structure (Dar and Presley, 2000).

The operation of Islamic banks has two aspects as pointed out by Khan (1997); the 'mechanics of it' and the 'spirit of it'. While the mechanics relate to fulfilling the Islamic legal requirements in its operations, the latter relates to faith. However, while all institutions (including non-Islamic ones) can implement the mechanics of Islamic banks by providing Islamic compatible financial contracts and transactions, every institution can't fulfill the spirit of an Islamic enterprise. This is what primarily distinguishes an Islamic bank from a conventional one.

Philosophically, Islamic bank operates based on the faith component which takes its course from Adl (social justice) and Ahsan (benevolence) (Khan, 1997). The implications of these concepts are fostering peace and tranquillity in an economy through the encouragement of free markets, helping the poor, profit and loss sharing, discouraging price controls, and forbidding financial contracts based on Riba (interest), Gharar (uncertainty), Maysir (speculation), hoarding and investments in impermissible activities (alcohol trading, gambling, gossip columns, pork production, and pornography). In Qur'an 5:90, Allah (SWT) warns as follows:

"O you who believe! Intoxicants (all kinds of alcoholic drinks), and gambling, and Ansab (animals slaughtered on altars), and Al-Azlam (arrows for seeking luck or decision) are abominations of Shaitan's handiwork. So avoid (strictly all) that (abominations) so that you may be successful."

The following sets of beliefs were advanced by Islamic banking: interest as a reward for savings has no moral basis; refraining from spending current income deserves no financial reward; and profiting from money requires transforming it into investments only, and prepared to accept risks and bring in the knowledge of other factors of production together (Presley, 1988). Therefore, the main function of the Islamic bank is to guide human development in line with the principles of Islam. According to Al-Harran (1993), it deals with all aspects of economic development but always within the framework of complete human development and never in isolation from this perspective.

\subsubsection{Sharia Principles and Profit and Loss Sharing (PLS)}

PLS model of finance was introduced by Islamic banks to offer non-interest loans in Muslim societies to protect their religious interest which strongly condemns interest. Islamic banks are not confined to Arab countries nor are they confined to Muslim countries (Jalaluddin, 1999). The PLS model is 
therefore applied by Islamic banks in non-Muslim countries. Most Islamic economists maintain that PLS is based on two major Islamic financing modes, namely; Mudarabah and Musharakah which are desirable in an Islamic context wherein reward-sharing is related to risk-sharing between transacting parties (Humayun \& Presley, 2000). In Islamic banking, therefore, investors and entrepreneurs both share in the results of the project. On this account, profit is shared in pre-agreed proportions; in the event of loss, all financial burden is borne by the capitalist and the entrepreneur only loses his labour (Iqbal \& Molyneux, 2005).

Zaidi and Mirakhor (1991) argued that profits calculations under the PLS scheme exclude the fixed cost of the interest charged on borrowed capital. This means under PLS modes of finance; the profit share of both the financier and entrepreneur is dependent on the soundness and success of the project. Thus, the financier's expertise is expected to enhance that of the entrepreneur to ensure efficient management and the highest possible productivity of the projects. In this vein, the PLS model of finance possesses outstanding features and ideals such as transparency, fairness, accountability, and most importantly, their combination of uncompromising religious truths with modern-day financial savvy (Jama, 2009).

\subsubsection{Islamic Banking Products}

I. Musharakah describes a form of partnership in which two or more persons come together to combine either their capital or labour, with the aim of sharing the profits/loss, enjoying similar rights and liabilities (Al-Harran, 1993). This implies that partners share the resulting gains or losses based on the capital or labour invested. However, in a situation where one partner has experience or exerts more effort than others, he or she can take an additional percentage of the profits based on an agreement between the two parties. Khan (2004) asserted that the period of Musharakah can be more or less than a year; the important thing is that Musharakah confers the right to closely monitor the activity of the business through being part of the management. Each partner in this type of contract has the right to withdraw under certain conditions if it causes no injury to other parties, and if communicated to the other parties. This makes a Musharakah contract non-binding (Abdullah, 1997).

II. Mudarabah is a partnership contract where investment is the sole responsibility of a capital provider (called Rab Al-mal) who has no right to participate in the management of the project which is carried out by an entrepreneur called Mudarib (Usmani, 2002). Even though the financier is not expected to partake in the management of the business, he can keep a watchful eye where he is doubtful (Khan, 2004). Like in Musharakah, the parties to this PLS financing arrangement are also two, the owner(s) of the fund and the entrepreneur. In Mudarabah, the loss if any is suffered by the Rab Al- mal only unless they are due to the Mudarib's conduct since he has not invested anything. His loss, however, is limited in the sense it is only his labour that has gone in futile (Usmani, 2002).

III. Manufacture Sale (Istisna) Facility, under Istisna agreement a seller undertakes to develop or manufacture a commodity with clear specifications and deliver it at an agreed price and time to the buyer. Nothing, however, is exchanged on spot or at the time of contracting which makes it the only forward contract where the obligations of both parties relate to the future. Profit for the bank constitutes the difference between the price it charged the client and the price it paid to the manufacturer.

IV. Deferred Payment Facility (Bai Bithaman Ajil) (Murabaha); Bai Bithaman Ajil (BBA) or simply Bai Mu'ajjal is a sale where payment of the price is deferred to a future date. Often it includes features of a Murabaha (cost-plus sale), which implies a sale on a cost-plus basis (Obaidullah, 2005). As in Murabaha, both parties involved in the transaction must know the cost and the mark-up. The transaction is regarded as Musawamah - where the buyer does not know the actual price paid by the seller to obtain the $\mathrm{good} /$ service. Musawamah is also a valid transaction.

V. Leasing (Ijara) Facility in simple terms Ijara means leasing or hiring of a physical asset. Ijara contract allows a client to enjoy/receive the benefit associated with ownership of the asset upon payment of predetermined rentals (Ujrat). Ijara is for a known period of time called Ijara period. The basic form of Ijara involves the bank acquiring an asset from a vendor and act as the owner of that asset, lease out the same to its client against predetermined rentals for an agreed period of time. Three parties may however be involved - lessor, lessee, and vendor.

\subsection{Empirical Literature Review}

Due to the failure of conventional banking practices, Islamic Banking is gradually being accepted by most countries in the world. Iran, Sudan, and Pakistan, for example, operate fullIslamic banking and financial systems, whereas countries like Algeria, Bahrain, Egypt, Malaysia, and Saudi Arabia operate a dual banking system (e.g. conventional and Islamic Banking Systems) (see Daud, Yussof \& Abideen, 2011; Hearn, Piesse \& Strange, 2010; and Zaher \& Hassan, 2002). According to Zaher and Hassan (2002), the significantly high growth rate of the Islamic Banking products in terms of sales, deposits, market share, profit, and size, resulted in non-Muslim countries especially Europe and America to introduce Islamic Banks and/or Islamic Banking products that are non-interestbased.

Apparently, the initiative of Islamic banking has gained widespread acceptance and increasing popularity as pointed out by Ahmed (2014) but despite that, the products of Islamic banks persistently meet huge criticism from various 
stakeholders (Khan, 2010). Most of these criticisms came from customers, who out of ignorance assume that there exists no apparent difference between Islamic bank products and services and conventional banking products; as such, most Islamic bank products are a mere replica of the latter (Butt et al 2011). Ahmed (2011) appropriately emphasizes this area part by asserting that Islamic banks must strive to develop Shariah-based compliant products instead of focusing only on Shariah-compliant and pseudo-Islamic products.

Choong and Liu (2006) are equally of the view that Islamic banking, at least as is being operated in Malaysia, diverges from the PLS principle and is in practice not specifically different from conventional banking. They accordingly propose that for purposes of analyzing the financial sector, Islamic banks should be treated in a similar way to their conventional counterparts. However, this is a minority view and may be less relevant for other countries. Most of the relevant literature suggests, albeit, using theoretical arguments rather than a formal empirical analysis, that Islamic banks pose risks to the financial system that in many regards differ from those posed by conventional banks. Risks unique to Islamic banks arise from the specific features of Islamic contracts, and the overall legal, governance, and liquidity infrastructure of Islamic finance.

There are other features that could also make Islamic banks less vulnerable to risk than conventional banks Siddiqui (2002) because the PLS schemes allow it to lessen any adverse economic condition on the asset side of the balance sheet; Islamic banks, for example, can pass through a negative shock on the asset side (e.g., a Musharakah loss) to the investment depositors (a Mudarabah arrangement). This means the risksharing arrangements provide another layer of protection to the bank. Also, the need to provide stable and competitive returns to investors, the shareholders' responsibility for negligence or misconduct (operational risk), and the more difficult access to liquidity put pressure on Islamic banks to be more conservative (resulting in less moral hazard and risktaking). Furthermore, because investors (depositors) share in the risks (and typically do not have deposit insurance), they have more incentives to exercise tight oversight over bank management.

Several studies have been conducted focusing on Islamic Finance, corporate customers, and the compatibility of Islamic Banking products and offerings in different countries and regions (see for example Woodley, 2009; Dasuki; Ahmad and Haron, 2002, \& Rustam et al, 2011). However, only little studies have been done on the Islamic banking products' viability (see, for example, Ali \& Hussain and Vahed $\&$ Vawda, 2008). In a recent study, Rahmi et al (2020) examine the perception of Islamic banking products among university students in Malaysia, imploring primary data, the result shows that while most of the respondents are familiar with and convinced that Islamic banking products are a viable alternative to their conventional counterpart, respondents are less convinced of adherence to Shari'ah, efficiency, and helpfulness of existing Islamic banks. This has made their overall perception to be negative. Saini et al (2011) conducted a similar study in South Africa, investigating the level of consumer awareness and use of Islamic banking products, they found that the usage of Islamic banking products is very low even among Muslim customers, citing a lack of efficiency, availability, and accessibility as the major reason.

Finally, Islamic banks have traditionally been holding a relatively larger proportion of their assets than conventional banks in reserve accounts with central banks or in correspondent accounts. So, even if Islamic investments are riskier than conventional investments, the question from the financial stability perspective is, whether these higher risks are compensated for by higher buffers. Is it possible to determine whether Islamic banking products are viable compared to conventional banking products? This is clearly an empirical question, the answer to which depends on the relative sizes of the effects discussed above, and it may in principle differ from country to country and even from bank to bank. However, very few studies attempted to provide an answer to this question in Nigeria (see Danbatta, 2011). The rest of this paper aims to contribute to finding the empirical answer to this question.

\subsection{Theoretical Framework}

This research uses the Goal Setting Theory and Classical Theory of Employment, developed by Locke (1968) and Jean Baptist (popularly known as J. B. Say) respectively.

The Goal Setting theory states that the intention to work towards a goal is a major source of job motivation. It also pinpoints the following:

1. Specificity of the goal: the goal has to be clearly stated or spelled out

2. The difficulty of assignment: it should be of moderate difficulty

3. Acceptance: there should be all-around involvement in goal setting by all those concerned.

The goal of setting up Islamic banks and developing Islamic banking products is to fill the gaps/vacuum created by conventional banking products in terms of their inability to provide Shariah-compliant banking products.

On the other hand, Say's law of markets is the core of the classical theory of employment. An early $19^{\text {th }}$-century French economist, J. B. Say, enunciated the position that "supply creates its demand". Therefore, there cannot be general overproduction and the problem of unemployment in the economy.

By this postulation, the supply of Islamic banking products will create its demand; and more important, as the products are being demanded ensures their viability. 


\section{METHODOLOGY}

\subsection{Method of Data Collection}

The primary source of data was used for this study. This involves the use of structured questionnaires that was administered to 335 respondents from the four Local Government Areas (LGA's) hosting JAIZ Bank branches in Kano state (the highest populated state in Nigeria) and JAIZ Bank staff members. It was designed in such a way as to capture the demographic and socio-economic characteristics of the sample respondents within the study area.

A two-stage purposive sampling technique was used during the survey for the selection of the respondents. The first stage which is called the primary unit involved the selection of four (4) Local Governments with JAIZ Bank presence in their area of jurisdiction. The second stage which is the second unit involved the selection of a total sample size of 335 respondents from the customers of the three branches and a cash centre of JAIZ Bank in Kano and staff of JAIZ Bank Plc representing $1 \%$ of the total number of customers and staff of the total branches.

\subsection{Model Specification}

\subsubsection{The Model of Demand of Islamic Banking Products}

To estimate the demand for Islamic banking products in this research, Ordinary Least Square (OLS) estimation techniques were employed. To examine the impact of customer characteristics on the demand for Islamic banking products, the researcher estimate using OLS techniques for the decisionmaking process on the use of Islamic banking products.

Following Addisu, (2006); Rahji \& Fakayode (2009); Oyedele et al., (2009); Rahji and Adeoti, (2010); Omonona et al., (2010) and Balogun \& Yusuf, (2011) with some modifications, the model was chosen for the analysis of the determinants of the viability of Islamic banking products incorporates socioeconomic factors into the usual economic approach within the framework of cross-sectional analysis. Therefore, for simplicity the binary choice model is of the form:

$\mathrm{Y}^{*}=\beta_{0}+\sum \beta_{\mathrm{i}} \mathrm{X}_{\mathrm{ij}}+\mu_{\mathrm{i}}$

$\mathrm{Y}^{*}$, the demand for Islamic products is an unobserved latent variable. What is actually observed is a binary variable say IP defined by:

Individual I takes Islamic products if IP $=1$

Individual I does not take Islamic products if IP $=0$

The assumption is that households are faced with a choice between two alternatives; that is to use Islamic banking products or to use conventional banking products for their trading activities. In this research, it is hypothesized that the probability of the customers deciding on a particular outcome depends on the households' demographic and other socioeconomic variables.

Then, the estimable equation become:
$\mathrm{IP}=$

$\beta_{0 \mathrm{i}}+\beta_{1 \mathrm{i}} \mathrm{AGE}+\beta_{2 \mathrm{i}} \mathrm{GEN}+\beta_{3 \mathrm{i}} \mathrm{INC}+\beta_{4 \mathrm{i}} \mathrm{REL}+\beta_{5 \mathrm{i}} \mathrm{CFI}+\mu_{\mathrm{i}} \ldots \ldots \ldots \ldots$

Where IP (Islamic Product) is a dummy variable taking a value of 1 if the individual takes Islamic products and 0 otherwise, $\mu_{i}$ is the random variable which takes care of other factors affecting the demand for Islamic banking products but not captured by the model and the rest of the variables are defined below.

$\beta_{0=}$ intercept

$\beta_{1}, \beta_{2}, \beta_{3}, \beta_{4}, \beta_{5}=$ slopes coefficient of age, gender, income, religion, and characteristics of financial institutions respectively.

AGE $=$ Age

GEN $=$ Gender

$\mathrm{INC}=$ Income

REL= Religion

$\mathrm{CFI}=$ Characteristics of Financial Institutions

Ordinary Least Square techniques were employed in this research in order to determine the factors affecting the demand for Islamic banking products among the customers. This was done from the perspectives of problems constraining customers from accessing loans and the relative importance of these problems on households. The various obstacles or constraints to the viability of Islamic banking products that deter customers from accessing the products were classified as the dependent (polytomous) variables. And it is defined in this research as religious perception, legal environment, income, public confidence/fear of risk, lack of collateral, lack of information, and distance/accessibility to credit facilities.

In this case, the choice of problems/constraints was modelled as a function of the demographic and socio-economic characteristics of customers. This can be presented as:

$\mathrm{PP}=\mathrm{f}(\mathrm{AGE}, \mathrm{GEN}, \mathrm{INC}, \mathrm{REL}, \mathrm{LE}, \mathrm{PC}$, and CFI)

Where PP is the set of obstacles/problems that can deter customers from sourcing Islamic banking products and the rest of the explanatory variables are as defined below.

AGE $=$ Age

GEN $=$ Gender

$\mathrm{INC}=$ Income

REL $=$ Religious Perception

LE $=$ Legal Environment

$\mathrm{PC}=$ Public Confidence

$\mathrm{CFI}=$ Characteristics of Financial Institutions

OLS model provided sufficient information on the likelihood of obtaining Islamic banking products, but could not provide a 
good estimation on the determinants of the number of products demanded.

Having some customers with zero/positive expenditure on Islamic products, there is evidence of categorical ordinal responses in the data. Therefore, to draw an inference on the variables responsible for determining the viability of Islamic banking products, OLS techniques were employed in this research. The model specified as:

\section{$\mathrm{Y}=\beta_{0 \mathrm{i}}+\beta_{1 \mathrm{i}} \mathrm{AGE}+\beta_{2 \mathrm{i}} \mathrm{GEN}+\beta_{3 \mathrm{i}} \mathrm{INC}+\beta_{4 \mathrm{i}} \mathrm{REL}+\beta_{5 \mathrm{i}} \mathrm{LE}+\beta_{6 \mathrm{i}} \mathrm{PC}+\beta_{7 \mathrm{i}} \mathrm{CFI}$} $+\mu_{\mathrm{i}} \ldots \ldots \ldots$ (4)

The latent variable $\mathrm{Y}$ is summarized as $0(\mathrm{y}=0), 100(\mathrm{y}=1)$, $200(y=2), 300(y=3), \mu_{i}$ is the standard normally distributed error term and the rest of the variables are as defined in tables below.

\section{RESULTS AND ANALYSIS}

\subsection{Results}

In this part of the study, determinants of the viability of Islamic banking products were considered in a regression framework. A multivariate regression model was adopted to identify the set of variables that determines the viability of Islamic banking products. The regression analysis was carried out using statistical software called Stata11.

Table 4.1: Repression Results

\begin{tabular}{|c|c|c|c|}
\hline Variables & Coefficient & t-ratio & P> $|\mathbf{t}|$ \\
\hline AGE & $\begin{array}{c}0.001104 \\
(0.0006848)\end{array}$ & 1.61 & 0.108 \\
\hline GEN & $\begin{array}{c}0.0985701 \\
(0.0247451)^{*}\end{array}$ & 3.98 & 0.000 \\
\hline INC & $\begin{array}{c}0.0866015 \\
(0.0235763)^{*}\end{array}$ & 3.67 & 0.000 \\
\hline REL & $\begin{array}{c}0.2805298 \\
(0.0286645)^{*}\end{array}$ & 9.79 & 0.000 \\
\hline LE & $\begin{array}{c}0.1507515 \\
(0.0247814)^{*}\end{array}$ & 6.08 & 0.000 \\
\hline PC & $\begin{array}{c}0.198605 \\
(0.0273194)^{*}\end{array}$ & 7.27 & 0.000 \\
\hline CFI & $\begin{array}{c}0.4299049 \\
(0.0294014)^{*}\end{array}$ & 14.62 & 0.000 \\
\hline Cons & $\begin{array}{c}-0.1939348 \\
(0.0395028)\end{array}$ & -4.91 & 000 \\
\hline
\end{tabular}

Source: Research computation using Stata 11
$\mathrm{R}^{2}=0.8471$
Adj. $R^{2}=0.8438$
Root
$\mathrm{MSE}=0.1863$

Note: *significant at $1 \%$

Various tests of Heteroskedasticity and Multicollinearity were conducted to ascertain the level of predictability of the coefficients. In the case of Heteroskedasticity, BreuschPagan/Cook-Weisberg test was conducted, and the result obtained shows that there is the presence of Heteroskedasticity, it is not Homoskedastic as desired (see the result below):

\subsection{Breusch-Pagan/ Cook-Weisberg Test for Heteroskedasticity}

Ho: Constant variance

Variables: fitted values of Y

$$
\operatorname{chi}^{2}(1) \quad=18.51
$$

Prob $>\mathrm{chi}^{2}=0.0000$

The results above show that there is a presence of Heteroskedasticity as prob $>\mathrm{chi}^{2}=0.0000$ which implies that the null hypothesis is rejected (Homoskedastic) and the alternative hypothesis (Heteroskedastic) is accepted. In order to remedy the problem identified above, a robust regression was re-estimated, and the results obtained are:

Table 4.2: Results of Robust Regression

\begin{tabular}{|c|c|c|c|}
\hline Variables & Coefficient & t-ratio & P> |t| \\
\hline AGE & $\begin{array}{c}0.001104 \\
(0.0006982)\end{array}$ & 1.58 & 0.115 \\
\hline GEN & $\begin{array}{c}0.0985701 \\
(0.0289146)^{*}\end{array}$ & 3.41 & 0.001 \\
\hline INC & $\begin{array}{c}0.0866015 \\
(0.0210735)^{*}\end{array}$ & 4.11 & 0.000 \\
\hline REL & $\begin{array}{c}0.2805298 \\
(0.040902)^{*}\end{array}$ & 6.86 & 0.000 \\
\hline LE & $\begin{array}{c}0.1507515 \\
(0.0272272)^{*}\end{array}$ & 5.54 & 0.000 \\
\hline PC & $\begin{array}{c}0.198605 \\
(0.0318413)^{*}\end{array}$ & 6.24 & 0.000 \\
\hline CFI & $\begin{array}{c}0.4299049 \\
(0.0503011)^{*}\end{array}$ & 8.55 & 0.000 \\
\hline Cons & $\begin{array}{c}-0.1939348 \\
(0.0417368)^{*}\end{array}$ & -4.65 & \\
\hline
\end{tabular}

Source: Research computation using Stata 11
$\mathrm{R}^{2}=0.8471$
Adj. $R^{2}=0.8438$
Root

$\mathrm{MSE}=0.1863$

Note: *significant at $1 \%$

The problem of Heteroskedasticity has been taken care of. The above regression result is now Homoskedastic. Therefore, all the interpretations of the variables are based on the estimated robust regression as contained in table 4.21

\subsubsection{Variance Inflation Factor Test of Multicollinearity}

VIF test was conducted to find out the level of relationship among the explanatory variables; that is, Multicollinearity and the results obtained are as follows:

Table 4.2.1: VIF Result of Multicollinearity

\begin{tabular}{|c|c|c|}
\hline Variable & VIF & $\mathbf{1 / V I F}$ \\
\hline CFI & 1.99 & 0.503305 \\
\hline REL & 1.58 & 0.632973 \\
\hline LE & 1.46 & 0.686125 \\
\hline PC & 1.40 & 0.716718 \\
\hline GEN & 1.34 & 0.747463 \\
\hline INC & 1.27 & 0.784914 \\
\hline
\end{tabular}




\begin{tabular}{|c|c|c|}
\hline AGE & 1.13 & 0.882572 \\
\hline Mean VIF & 1.45 & \\
\hline
\end{tabular}

Source: Research computation using Stata 11

Table 4.19 shows that the variables have low Variance Inflation Factor values (below 5) hence all the variables are retained for further analysis.

\subsubsection{Overall Significance Test}

F test was conducted to ascertain if the variables are jointly significant and the results show that the variables are good hence they are retained for further analysis as the null hypothesis states that both coefficients do not have effect on the viability of Islamic banking products (see results of the test below):

$$
\begin{aligned}
& F(6,327)=563.02 \\
& \text { Prob }>F=0.0000
\end{aligned}
$$

Thus, the estimated regression equation for viability of Islamic banking products in JAIZ Bank Plc 2019 is estimated as follows:

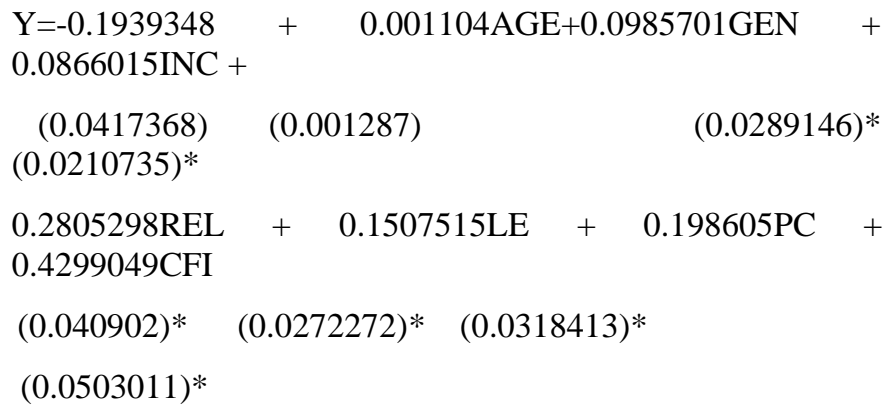

Note: figures in parenthesis are the various standard errors of the respective coefficients.

\section{CONCLUSION AND RECOMMENDATION}

\subsection{Conclusion}

This research has examined the major determinants of the viability of Islamic banking products (as identified by the research) which include; Age, Gender, Income, and Religion of users of Islamic banking products. It also examined the Legal Environment, Perceived Public Confidence, and Characteristics of Financial Institutions in terms of being risks averse, bureaucracies in credit approval processes, and product development policies. The research also discovered that age does not have any impact on the viability of Islamic banking products in JAIZ bank. However, it discovered that the other variables (gender, income, religion, legal environment, public confidence, and characteristics of financial institutions) have a significant impact on the viability of Islamic banking products in Islamic financial institutions. Conclusively, the researchers discovered that Islamic banking products are viable enough to add to the bottom line/profitability of Islamic financial institutions.

\subsection{Policy Recommendations}

Based on the findings of the study, the following recommendations were made:

$\checkmark \quad$ In line with the objective of achieving efficient liquidity management, JAIZ Bank and especially the regulatory agencies like Central Bank of Nigeria (CBN), Securities and Exchange Commission (SEC), NDIC, Nigeria Stock Exchange (NSE), the Legislature amongst others have to establish institutions that will provide avenues where Islamic banks can invest their excess liquidity without having to go outside the line drawn to them by Shariah. CBN needs to develop an Islamic interbank market to provide an environment where Islamic banks can meet and transact in an Islamically acceptable instruments without having to use the same interbank market with their conventional counterparts. There is a need for the development of an Islamic capital market where shares of Islamic banks can be easily traded and provide a platform where Islamic banks can access/raise additional capital.

$\checkmark \quad$ JAIZ bank should further invest more in product innovation and the provision of adequate staff training and development to drive the growth and development objective of the bank through customer satisfaction. This is in line with the customer satisfaction objective of this study. JAIZ Bank should re-examine its processes to eliminate all unnecessary bottlenecks that will impede the bank's ability to process customers' requests in good time as characteristics of financial institutions always leads to delays in processing customers request in many financial institutions. However, this should not compromise the rules governing Islamic banking transactions. JAIZ Bank should devise means of identifying customers who experience an increase in their income with a view of convincing them to patronize more of the bank's products. This will undoubtedly increase the bank's income.

$\checkmark$ CBN should push for the provision of enabling legal environment through enriched legal framework as doing so will boost the patronage for Islamic banking products in the country. Being the pioneer Islamic bank in Nigeria, JAIZ bank has to do a lot to sensitize the public about its products and the uniqueness of its services; though it's expensive to engage in a massive awareness campaigns, it can engage in the use of averagely low-cost awareness campaign through the use of pamphlets highlighting the features and benefits of their products and services. The more the public is confident in the suitability of JAIZ Banks products to satisfy their needs, the more the patronage of the bank's products will lead to more returns on investment for the bank.

$\checkmark$ Aggressive branch expansion is also needed to satisfy the needs of an already existing market for 
Islamic banking products in Nigeria. There is the need for the establishment of departments in Nigerian courts that will adjudicate cases emanating from Islamic financial dealings.

$\checkmark$ Persistent and continuous marketing is needed to boost the patronage level of Islamic banking products offered by JAIZ Bank Plc.

$\checkmark$ Finally, more future studies are needed in this area to create a more comprehensive roadmap for Islamic banks on the determinants of the viability of Islamic banking products. This would enhance Islamic banks to improve on their products and services which will, in turn, lead to expanding the usage of Islamic banking services and in general, the Islamic banking system.

\section{REFERENCES}

[1] Abdul Majid, A. R. (2003). Development of Liquidity Management Instruments: Challenges and Opportunities. International Conference on Islamic Banking: Risk Management, Regulation, and Supervision. Jakarta, Indonesia.

[2] Ahmad, N., \& Haron, S. (2002). Perceptions of Malaysian corporate customers towards Islamic banking products and services. International Journal of Islamic Financial Services, 3(4), 13-29.

[3] Ahmed, H. (2014). Islamic banking and Shari'ah compliance: a product development perspective. Journal of Islamic finance., 3(2), 15-29.

[4] Ahsan, A. S. M. (1988). Islamic Banking in Perspective, in Molla, R. I. Et al., (eds) Frontiers and Mechanics of Islamic Economics. Sokoto, University of Sokoto Press

[5] Alam, M. N. (2003). Micro Credit through 'Bai-Muajjal' Mode of Islamic Banking Financing System. Conference of SANABEL (Canada).

[6] Al-Harran, S. A. S. (1993). Musharakah Financing: Concept, Principles, and Financing. Institute for Policy Research, Malaysia.

[7] Al-Harran, S. A. S. (1993). Islamic Finance: Partnership Financing. Pelanduk Publications, Malaysia.

[8] Asquith, P., Gertner, R. \& Scharfstein, D. (1994). Anatomy of Financial Distress: An Examination of Junk-Bond Issuers. Quarterly Journal of Economics, vol. 109 No.3

[9] Balogun, O. L. \& Yusuf, S. A. (2011). Determinants of Demand for Microcredit among the Rural Households in South-Western States. Nigeria Journal of Agriculture \& Social Science

[10] Balogun, O. L., \& Yusuf, S. A. (2011). Effect of Social Capital on Welfare of Rural Households in South-Western States. Nigeria Journal of American Sciences (ISSN: 1545-1003). Available online at http://www.americanscience.org

[11] Choong, B. S. \& Liu, M. (2006). Islamic Banking: Interest-Free or Interest-Based? Available on-line at SSRN: http://ssrn.com/abstract $=868567$

[12] Danbatta, L., B. (2011). An Empirical Study on the Viability of Islamic Banking System in Nigeria, IIUM Institute of Banking and Finance International Islamic University Malaysia

[13] Dar, H. \& Presley, J. (1999). Islamic Finance, a Western Prospective. International Journal of Islamic Financial Services

[14] Dar, H. \& Presley, J. (2000). Lack of Profit Loss Sharing in Islamic Banking: Management and Control Imbalances. See online:

www.researchgate.net/publication/2440824_Lack_of_Profit_Loss _Sharing_in_Islamic_Banking_management_and_Control_Imbala nces/links/0e5fa778f0c41c4932e1a446.pdf

[15] Dogarawa, A. B. (2011). An Exploratory Study of the Economic Viability of and Opportunities for Islamic Banking in Nigeria. International Journal of Research in Management, Economics and Commerce, Volume2 Issue 1 ISSN: 2250-057X. Available online: indusedu.org/IJRMEC/jan(vol1\%20 issue3)/1.pdf
[16] Galbraith, J. K. (1972). The New Industrial State. (New York: New American Library).

[17] Hanif, M. (2016). Profit and Loss Sharing in Islamic Banking and Finance. Islamic Finance Review, Vol 5

[18] Iqbal, M. \& Molyneux, P. (2005). Thirty Years of Islamic Banking: History, Performance and Prospects. See on-line: kantakji.com/media/1878/9008.pdf

[19] Jalaluddin, A. (1999). Attitudes Towards and the Probability of Applying the Profit/Loss Sharing Method of Finance by Western Small Business Firms' in Islamic Banking and Finance: Current Developments in Theory and Practice. Anthony Rowe Ltd, Britain.

[20] Jama, S. H. (2009). Islamic Finance Industry: A Safe Heaven. Almanar: Internal Information Bulletin of Islamic Development Bank.

[21] Khan, M. \& Mirakhor, A. (1989). The Financial System and Monetary Policy in an Islamic Economy, JKAU: Islamic Economics, Jeddah Vol. 1, No. 1, pp. 39-57.

[22] Khan, T. (1997). An Analysis of Risk Sharing in Islamic Finance with Special Reference to Pakistan. PhD Dissertation (unpublished), Loughborough University, Loughborough.

[23] Khan, M. F. (1997). Social Dimensions of Islamic Banks in Theory and Practice. Islamic Research and Training Institute, Islamic Development Bank, Manuscript.

[24] Khan, T. (2004). Risk Management in Islamic Banking: A Conceptual Framework. Distance Learning Lecture.

[25] Obaidullah, M. (2005): "Islamic Financial Services". Scientific Publishing Center, King Abdulaziz University.

[26] Oyedele, K. F., Ayolabi, E. A., Adeoti, L. \& Adegbola, R. B. (2009). Geophysical and Hydrogeological Evaluation of Rising Groundwater Level in the Coastal Areas of Lagos, Nigeria, Bull Eng Geol Environ.

[27] Oyeniran, B. F. (2012). Can Islamic Banking Work in Nigeria. Journal of Sustainable Development in Africa (Volume 14, No. 2, 2012) ISSN: 1520-5509, Clarion University of Pennsylvania, Clarion, Pennsylvania.

[28] Presley, J. H. (1988). Directory of Islamic Financial Institutions, London. Croom Helm, Beckenham, London. "Product Differentiation. Available on-line at www.marketing91.com/product-differentiation/ accessed on 23/03/2021.

[29] Rahji, M. A. Y., Fakayode, S. B. (2009). A Multinomial Logit Analysis of Agricultural Credit Rationing by Commercial Banks in Nigeria. International Research Journal of Finance and Economics 24(8):90-100. Published by Eurojournals Academic Publishers Inc England. Available on-line at http://www.eurojournals.com/irjfe 24 08.pdf.

[30] Rahji, M. A. Y. \& Adeoti, A. I. (2010). Determinants of Agricultural Credit Rationing by Commercial Banks in SouthWest Nigeria. International Journal of Finance and Economics, Vol. 37. Available on-line at http://www.eurojournals.com/irjfe_37_01.pdf.

[31] Rahmi, M., Azma, N., Obad, F. M., Zaim, M., \& Rahman, M. (2020). Perception of Islamic banking products: Evidence from Malaysia. Journal of Business and Enviromental Studies 10-3 (2020) 35-42.

[32] Rustam, S., Bibi, S., Zaman, K., Rustam, A., \& Haq, Z. U. (2011). Perceptions of corporate customers towards Islamic banking products and services in Pakistan. The Romanian Economic Journal, 41(4), 107-123.

[33] Saini, Y. Bick, G, \& Abdulla, L. 2011. Consumer awareness and usage of Islamic banking Products in South Africa, South African Journal of Economic and Management Sciences, 14(3): 298-313.

[34] Siddiqui, S. H. (2001). Islamic banking: true modes of financing. New Horizon, 109(2), 15-20.

[35] Singh, T. (2013). The Outlook of Islamic Banking Model: Global \& India Perspective. Public Policy and Administration Research ISSN 2224-5731 (Paper) ISSN 2225-0972 (Online) Vol.3, No.7, $2003 . \quad$ See on-line: http://www.google.com.ng/url?sa=t\&rct=j\&q=\&esrc=s\&source=w 
$\underline{\text { eb } \& c d=4 \& c a d=\text { rja\&uact }=8 \& v e d=0 C C o Q F j A D a h U K E w j 77 a T 0 h 6}$ 3HAhWBvRQKHdbND9U\&url=http\%3A\%2F\%2Fwww.iiste.org \%2FJournals\%2Findex.php\%2FPPAR\%2Farticle\%2Fdownload\% 2F6962\%2F7053\&ei=UDnQVfuFEYH7Utabv6gN\&usg=AFQjC NEenYpZi3znULYIORDXwV cwS9qA\&bvm=bv.99804247,d.d24 accessed on $16 / 03 / 2021$

[36] The Economist (print edition) (2008): Faith-Based Finance. September 4. 14. The New Straits Times Supplement 30 August 2008, P.7).

[37] Usmani, Muhammad Taqi (2002). An Introduction to Islamic Finance. Kluwer Law International

[38] Usmani, M. I. A. (2002). Meezan Banks Guide to Islamic Banking. Darul Ishaat, Pakistan.

[39] Vahed, G. \& Vawda, S. (2008). The Viability of Islamic Banking and Finance in a Capitalist Economy: A South African Case Study. Journal of Muslim Minority Affairs, 28(3): 453-472.

[40] Woodley, S. (2009). Growing Interest in Islamic Finance. W ashington, DC: The Diplomatic Courier: A Global Affairs Magazine.

[41] Zaher, T. S. \& Hassan, M. K. (2002). A Comparative Literature Survey of Islamic Finance and Banking. Financial Markets, Institutions and Instruments.

[42] Zaidi, I. \& Mirakhor, A. (1991). Stabilization and Growth in an Open Islamic Economy. Review of Islamic Economics. 